\title{
Уханов А.Д. \\ Социокультурный подход как методика постижения права: проблемы и перспективы
}

НИУ «Высшая школа экономики»

(Россия, Москва)

doi:10.18411/spc-20-10-2017-11

idsp: 000001:spc-20-10-2017-11

Современная «методологическая ситуация» в общей теории права характеризируется обширным приращением исследовательского «арсенала» для познания права. К числу наиболее популярных методологических стратегий следует отнести социокультурный подход [4]. Являясь методологией постижения права, позволяющей связать право с социальными и культурными факторами, социокультурный подход не лишен ряда недостатков. Так, на наш взгляд, проблематичной стороной социокультурного подхода является его методической значение и содержание при познании права и правовой реальности.

Следует отметить, что методология является интегрированным феноменов и включает в себя не только онтологические предпосылки познания и гносеологические идеи о его природе, трансформируя всё это в метод познания, но так же способы и приёмы его осуществления. Если метод является концептуальным путём познания, тесно связанным с самой теорией, и отражающим её общие преставления при обращении к тому или иному объекту, то средства и приёмы образуют собой методику познания, вырабатываемую на основе метода и представляющую собой конкретные шаги на пути познания. Под методикой исследования понимается конкретная, пошаговая процедура познания, определяющая деятельность исследователя.

Представляется, что большинство авторов, провозглашающих приверженность к социокультурному подходу к праву, делают это скорее интуитивно, нежели четко выстраивает шаги познания. Само по себе данное обстоятельство нельзя считать негативным, поскольку исследователь, использующий социокультурный подход, действует в соответствии с его общей логикой.

Многие работы, посвященные социокультурным основаниям права, государства и власти, вызывает массу вопросов в части отнесения тех или иных факторов к социокультурным факторам, обуславливающим специфику права в отечественном пространстве [4]. Не понятно, почему именно «это» относиться к устойчивой социокультурной стороне права, государства, власти и в целом правовой сферы жизни общества. Так же не всегда ясно, почему некоторым факторам придаётся определяющее значение, а другие моменты опускаются.

Таким образом, методическая сторона социокультурного подхода является достаточно слабой и малоразработанной, что сказывается на эвристической значимости социокультурных исследований. Вероятно, это связано с тем, что социокультурный подход только недавно сталь использоваться учеными юристам и на данном этапе идёт его теоретико-методологическое оформление в рамках юридической науки.

Возможно, что общая теория права в целом относиться с методике как не очень важному элементу методологии и отдаёт её на откуп самому исследователю. Так Ю. Ю. Ветютнев отмечает, что «учебники по истории и методологии юридической науки написаны таким образом, что невозможно из них толком понять, как проводить научные исследования. Там есть всё. Там есть и проблемы, дискуссии, и какие-то поиски исходных оснований правового познания, рассмотрение разных подходов и парадигм. Но рецептов исследования, технологий и процедур исследования там, как правило, нет (курсив мой - А. У.).» [2, с. 110]. 
Однако не все разделяют необходимость наличия в юридической науки рецептов, технологий и процедур, т.е. методики, исследования. Например, Д. А. Керимов, отмечая, что «первичная обработка эмпирического материала не осуществляется каким-то заранее подготовленным набором процедур, а имеет бесконечное множество вариантов, и каждый исследователь использует для этой цели не только уже применявшиеся ранее методические и технические средства, но и, опираясь на свой опыт (если угодно, даже на интуицию), самостоятельно изобретает их по ходу исследования применительно к своеобразию изучаемого объекта» [1, с. 41].

Похожей позиции придерживается В. С. Нерсесянц, который рассуждая о новом знании и процедурах научных открытий в юриспруденции, замечает, что «неизвестным остается как само это предстоящее новое, так и, разумеется, сам конкретный способ его открытия .... так что нет и не может быть правила открытия нового, методики о том, как конкретно и какое именно новое открыть. Иначе получилось бы, будто уже заранее известно то новое, которое пока как раз и остается неизвестным (курсив мой - А. У.)» [3, c. 15-16].

Подводя итог следует заключить, что социокультурный подход нуждается в конкретизации в виде методики, однако она не должна абсолютизироваться и подменять метод познания, а органически его дополнять, делая более понятным и практичным для исследователя.

Работа выполнена при финансовой поддержске гранта Президента РФ № мд-6669.2016.6

$$
* * *
$$

1. Керимов Д.А. Методология права (предмет, функции, проблемы философии права): монография. М., 2001. $-560 \mathrm{c}$.

2. Мамычев А.Ю. Социокультурные (архетипические и ментальные) основания публично-властной организации общества: монография / А. Ю. Мамычев, В. Я. Любашиц, А. Ю. Мордовцев и др. - М., 2017. - $187 \mathrm{c}$.

3. Нерсесянц В.С. Общая теория права и государства: учебник. - М., 2012. - 560 с.

4. Овчинников А.И. Архетипические и социокультурные основы правопонимания и правовой политики российского государства: монография / А. И. Овчинников, А. Ю. Мамычев и др. Владивосток, 2015. - 290 с.

\section{Уханов А.Д.}

\section{Концептуально-правовая интерпретация архетипа в современной теории права}

\section{НИУ «Высшая школа экономики»} (Россия, Москва)

doi:10.18411/spc-20-10-2017-12

idsp: 000001:spc-20-10-2017-12

В современной юридической науке всё чаще встречается термин «правовой архетип», используемый для описания чего-то устойчивого в праве (правовой реальности). Единое понимания в настоящий момент отсутствует, что требует рассмотрения концептуально-правовых интерпретаций архетипа.

Прежде всего, следует заметить, что первым, кто предложил использовать термин «архетип» в правовых исследованиях был К. В. Арановский, более того, именно он предположил «говорить о правовых архетипах». Его подход можно обозначить как смешанный или психолого-культурологический, поскольку хотя национальная культура и является «хранилищем» архетипов, тем не менее, они имеют психическую природу. Т.е. сущность архетипа лежит в области психического, однако рассмотреть его или объективно обнаружить его можно только через культуры, в которой он 